Hypotheses

\title{
Analysis of Market Orientation on Business Performance in the Multinational Service Industries
}

\author{
Martin Owusu Ansah and Richard Chinomona \\ School of Economic and Business Sciences, University of the Witwatersrand, Johannesburg - South Africa
}

\section{Article history}

Received: 01-01-2017

Revised: 09-01-2017

Accepted: 09-02-2017

Corresponding Author:

Martin Owusu Ansah

School of Economic and

Business Sciences, University

of the Witwatersrand,

Johannesburg - South Africa

Email: owusumartin97@yahoo.co.uk

\begin{abstract}
The paper examined the extent of market orientation on business performance in the multinational service industries in Ghana. It applied the behavioral viewpoint of market orientation measurement using MKTOR scale as a base in eliciting information from eleven marketing managers through in - depth interview while one hundred and sixty-three marketing managers were also surveyed using structured questionnaires. Structural Equation Modelling (SEM) statistical technique was used in analysing the data using Partial Least Square (PLS) software version 3.0. The findings revealed that, customer orientation and competitor orientation have significant positive relationships with business performance of the multinational service companies' activities whereas, inter-functional coordination did not have any influence on business performance. The study contributes to the negligible studies on market orientation measurement as a uni-dimensional construct as well as the limited studies on marketing managers as drivers of market oriented activities in the SubSaharan African countries.
\end{abstract}

Keywords: Orientation, Inter-Functional, Competitor

\section{Introduction}

Market orientation has become an important research subject matter in business research for some time now (Hult and Tomas, 2011; Murray et al., 2011; Agrawal, 2012; Spillan et al., 2013; Ozturan et al., 2014; Š́lyová et al., 2016). According to a study by Herhausen (2016), he stated that, firms with market orientation culture are able to attain better monetary and business performance even in tricky market situations. Fraj-Andrés et al. (2009) also observed that, promoting business performance strategy is dependably connected to the marketing practices of the business. The execution of a suitable marketing activity promotes superiority of a firm's activities and strengthens the competiveness and market share of the firm (Ghouri et al., 2011). It therefore becomes ruinous for organizations to ignore the consequence of market oriented activities in their business setup (Salminen, 2006; Smirnova et al., 2011; Theodosiou et al., 2012). The difficulty in assessing marketing performance stems from the fact that, its measurement is basically depended on external irrepressible factors such as customers and competitors (Neely, 2002). According to Kumar et al. (2011a; 2011b), the two foremost influential rudiments of the peripheral environment are customers and competitors. An organisation is not likely to survive once it does not uphold a market oriented culture in their business activities (Attia, 2013). Š́lyová et al. (2016) posited that, it was an indispensable on the part of organisations to certify well-timed running of market oriented policy, that is expected to replicate the market circumstances and continue to the current market inclination. The proliferation of companies and products on the markets have made consumers more sophisticated to be satisfied in both emerging and developing economies. Kotler (2010) observed that, consumers now know their rights and they persevere on their rights; for that reason, organizations ought to be customer-driven so as to stay put in their businesses. Kurt et al. (2006) also stressed that, a well-built economies characterized by strong demand require companies to embrace utmost intensity of market orientation. The change in taste and preference of consumers in the current Ghanaian business environment has made it imperative for organizations to alter their strategic marketing activities in meeting the needs of the people. Ansah (2016) observed that, there were limited studies on multinational activities and market orientation in Ghana-specifically with marketing 
managers in determining the oriented activities of the firm. Hajipour et al. (2010) researched on market orientation and advised that, studies on marketing activities necessitate marketing executives or managers to be used as respondents other than general managers in organizations. Employing marketing managers on market oriented activities of companies was more likely to enrich academic literature and at the same time provide a clear guideline to organisations on their market activities. Verbekea et al. (2016) opined that, a study on multinational companies in the current international business environment has a propensity to present both theoretical understanding and practical implications to deal with processes of adopting best business practices.

In recent years, an increasing body of literature has identified some gaps associated with studies on market orientation and business performance from the perspective of developing countries and they are provided as follows: First and foremost, there are limited studies on multinational activities in Africa and Ghana. According to a study by Merchant et al. (2011), they observed that, there was not much research carried out on multinational activities outside of the United States. The idea was finely tuned by Murphy and Li (2012) who also argued that, not much research has been conducted on multinational activities in Developing countriesespecially in the Sub-Saharan Africa: Which was also made evident by Ansah (2016) on the limited nature of studies on multinational companies in Africa. Secondly, Van Raaij and Stoelhorst (2008) posited that, there were various concerns associated with the measurement of market orientation. While many researchers assess the concept as a uni-dimensional concept and other authors such as Ansah (2016) prefer market orientation to be analyzed from multi-dimensional perspective so as to understand the significance of each component of the orientation. Morgan et al. (2009) also recommended for future researchers to assess the value of market orientation in organizations-especially on its measurement. Racela et al. (2007: 146); Mokhtar et al. (2009; Suliyanto and Rahab, 2012) all observed that, research on market orientation, as a concept, was still inadequate with limited studies in developing nations like Asia and Africa. Finally, there is a problem of limited studies on marketing managers, particularly on multinational business activities in developing African countries. Puck et al. (2008) observed that, managers who are concerned with managerial sustainability ought to be studied and analyzed carefully, in order to have an international perspective. According to Morgan et al. (2009; Merrilees et al., 2011), empirical testing and assessment of the significance of marketing activities to a firm's performance is limited in the extant literature. Marketing managers have responsibilities towards the development of teams for work performance in organizations (Comu et al., 2011).

\section{Significance of the Study}

The scant literature on multinational activities in developing countries, measurement of market orientation coupled with limited literature on marketing managers have necessitated the study. The study therefore aimed at examining the influence of market orientation on business performance through the viewpoint of marketing managers from multinational service industries in Ghana.

The next section presents the study's objectives; the theoretical grounding of the study; followed by the study's conceptual model and hypotheses development. The subsequent section describes the research methods, measurements and data utilised in the study. The final section summarises the results, discusses their implications for theory and managerial practice; provision of direction for future research. At this backdrop, the present study has framed the following objectives:

- To examine the relationship between customer orientation and business performance of multinational service industries in Ghana

- To determine the association between competitor orientation and business performance of multinational service industries in Ghana

- To analyse the connection between Inter functional coordination and business-performance of multinational service industries in Ghana

\section{Literature Review}

The review of the study's literature explains the theoretical literature and empirical literature. It started with the explanation of the resource based view theory as the study's theoretical foundation before the empirical literature is explained afterwards.

\section{The Resource-Based View}

Resource-Based View (RBV) was propounded by Wernerfelt (1984) as a bunch of possessions and means that are put together to build up on companies' competencies. According to Barney (2001; Progoulaki and Theotokas, 2010; Merrilees et al., 2011), the inner resources of companies are likely to enable them to have competitive advantages over their competitors. It simply explains that, the internal wealth of a company adds to its competitive advantage. Merrilees et al. (2011) observed that, companies' resources comprised: The material resources, capital resources as well as the human capital. The financial position of the multinational companies is more likely to enable them to acquire the required marketing personnel whose activities are more likely to turn the fortunes of these companies marketing activities around. Based on the underpinning, the current study views 
market orientation activities to be embedded in established internal capabilities-regarding material, capital as well as human resourced based in drafting a strong market oriented activities in ensuring a successful marketing performance, leading to the business performance of such companies.

\section{Empirical Literature}

The empirical literature comprised: Market orientation, business performance and multinational companies.

\section{Market Orientation}

Narver and Slater (1990) revealed that, market orientation has three diverse dimensions that outline the required organisational culture. They were: Customer orientation, competitor orientation and inter-functional coordination. Researchers such as: McCarthy and Perreault (1993; Kotler, 1994) also supported the definition of Narver and Slater by suggesting that, marketing concept normally put together three focal components: Customers, inter-functional coordination and profitability. According to Ngo and O'Cass (2012), the idea of organisations becoming market-oriented give credence to keeping close to the marketplace in generating better client value. Šályová et al. (2016) defined marketing orientation as an established concept with a broad spectrum of approaches, methods and tools that are used for achieving sustainable competitive advantage. Kotler and Armstrong (2011: 29) reiterated that, features of market orientation specify a strong client focus and an appreciative of organisational strengths and weaknesses. Marketing competencies ought to be seen as marketing practices that support policies - which comprised: Elements of the marketing mix, market research and market management (Merrilees et al., 2011). Zebal and Goodwin (2012:339) opined that, market orientation has always become an extended figure of marketing orientation. The current study employed Narver and Slater's (1990) definition which suggested that, market orientation was an activity that comprised three varied dimensions namely: Customer orientation, competitor orientation and inter-functional coordination.

\section{Business Performance}

Vieira (2010: 49) defined business performance as an idea of doing a particular work coupled with the result achieved at the end of doing that work. According to Kotler and Armstrong (2011: 65), business performance was a multidimensional construct with diverse interpretation - which relies on a diversity of factors. Capon et al. (1990; Lee and Madhavan, 2010) observed that, business performance is habitually determined by using the Return On Assets (ROA). Baker and Sinkula (2009) also opined that, business performance was calculated through sales revenue, return on investment as well as return on assets. Authors such as: Kohli and Jaworski (1996; Narver and Slater, 1990; Dwairi et al., 2007; Olavarrieta and Friedmann, 2008; Morgan et al., 2009) as well as Ngo and O'Cass (2012) all observed that, business performance denote a subjective process that has methodically been used by many researchers. Cano et al. (2004) opined that, subjective measures were appropriate indicators to measure business performance. The study employed the definitions of Ruekert et al. (1985; Kohli and Jaworski, 1996) towards business performance in a subjective way by assessing companies' sale value growth, return on sales growth as well as the overall market performance.

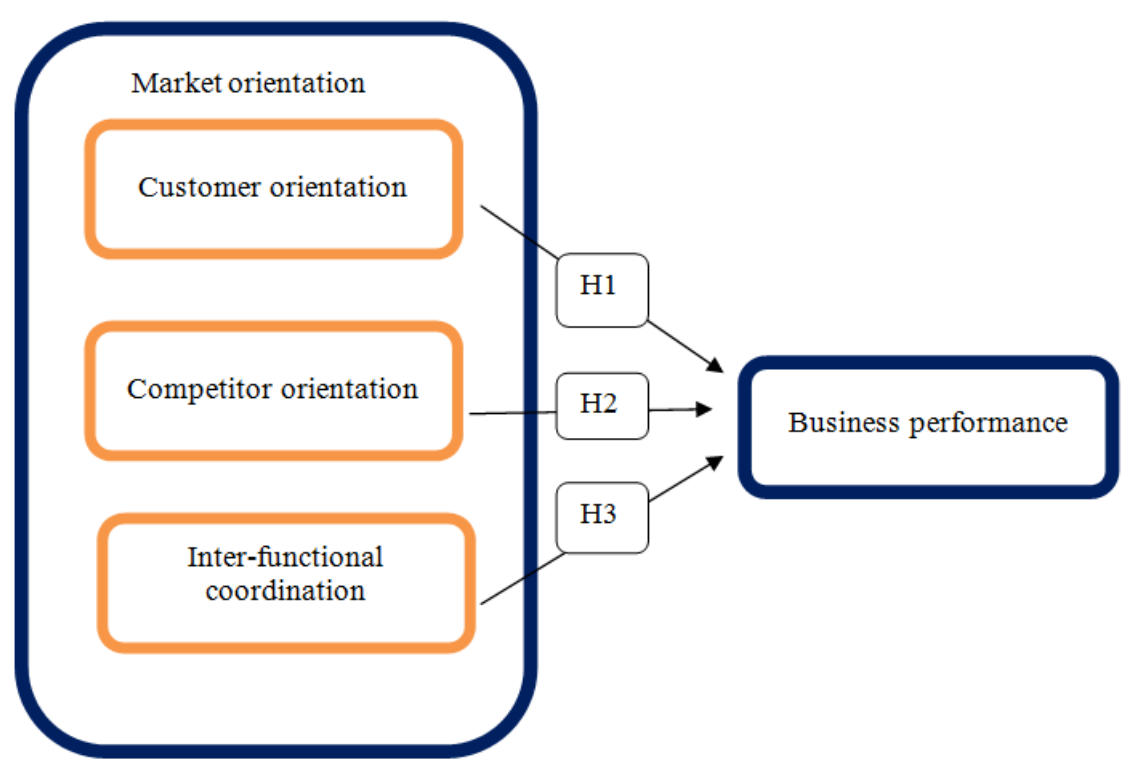

Fig. 1. The study's conceptual model 


\section{Multinational Companies (MNCs)}

An extensive definition of what represent a multinational company (MNC) has not been lucid in both academic literature and in policy. Buckley and Casson (2009) defined a multinational company as a corporation that has interrelated business position in more than two countries. The OECD (2008) also defined an $\mathrm{MNC}$ as a direct investment company that has a direct investor in another country and controls $10 \%$ or more of the ordinary shares or power in another country. MNC was also defined as an incorporated organisation that comprised a parent company and its subsidiary affiliate companies abroad (UNCTAD, 2009). According to Spero and Hart (2010), a multinational company was a company that preserve its foreign overseas direct investments in more than one country. Shah et al. (2012) termed a multinational company as a business venture that maintains direct investments in a foreign country. The current study employed the definition of Shah et al. (2012) who defined a multinational company as a business venture that controls direct investments in another country.

\section{Hypothesis Development}

A collection of research works has focused on the relationship between market orientation and business performance (Fraj-Andrés et al., 2009; Edigheji, 2010; Zebal and Goodwin, 2012; Dubihlela, 2013). According to Ghouri et al. (2011), the implementation of a good market orientation was more probable to lead to firms' performance. Hortinha et al. (2011) observed a positive relationship between market orientation and business performance. Researchers such as: Kohli and Jaworski (1996; Slater and Narver, 1994; Lado and Maydeu-Olivares, 2001; Yoon and Lee, 2005; Lai et al., 2009; Mahmoud et al., 2010; Smirnova et al., 2011; Bahman and Mehdi, 2011; Mashahadia et al., 2016) have all observed a positive relationship between market orientation and business performance. According to Herhausen (2016) market orientation has an incremental positive effect on business performance. This study therefore hypothesises that:

H1: Market Orientation (customer orientation) has a significant positive relationship with business performance

H2: Market Orientation (competitor orientation) has a significant positive relationship with business performance

H3: Market Orientation (inter-functional coordination) has a significant positive relationship with business performance

\section{Research Methodology}

The procedure that was used in collecting and analysing the study's data is explained below:

\section{Study Population}

The population of the study comprised all marketing managers in the various service multinational companies in Ghana. The service industries comprised: The banking industry, the insurance and financial institutions, the telecommunications companies as well as other support multinational service companies in the country.

\section{Study Sample}

Purposive and snowballing sampling techniques were employed. It consisted of 163 managers who were sampled from: Accra, Kumasi, Takoradi and Koforidua - which were basically the four business cities in Ghana. It included both expatriate managers of other countries as well as the native Ghanaians as managers for the multinational companies. Interviews and questionnaires were used in eliciting the views of the managers as part of the study's data collection process in getting the sample.

\section{Measurement Scale and Instrument}

Research scales were modified to suit the previous adapted works. Proper changes were made in aligning the current research context and purpose. Market orientation (competitor orientation) used a four item construct which was adapted from Narver and Slater (1990); Market orientation (customer orientation) employed a four item construct which was adapted from Narver and Slater (1990); Market orientation (Interfunctional orientation) used a four item construct which was adapted from Narver and Slater (1990) while business performance also employed a four item scale which was adapted from Ruekert et al. (1985) as well as Kohli and Jaworski (1996). The measurement items were measured on a seven point Likert scale that was anchored by $1=$ strongly disagree to $7=$ strongly agree. According to O'Sullivan and Butler (2009:1352) Likert scale helps in capturing attitudes of participants in business studies.

\section{Validity of the Study}

The validity of the interview guide was evaluated by two senior marketing lecturers of the Marketing Department from the Kwame Nkrumah University of Science and Technology, Ghana as well as two lecturers from the Marketing Department of the University of Witwatersrand in South Africa. Some of the questions were modified while others were deleted. The study's questionnaire was also validated statistically.

Discriminant validity was determined quantitatively through a comparison of the square root of the study's Average Variance Extracted (AVE) from the various variables using the application by Fornell and Larker (1981). It was observed that, the values of the root square of the AVEs of the study's variables such as competitor 
orientation, customer orientation, Inter-functional coordination as well as business performance were all greater than their respective individual correlations. It demonstrated that, the measurement item of each construct was powerfully connected to its underlined constructs signifying that, a discriminant validity had been established as observed by Chin (2010).

The convergent validity of the study was assessed using the various factor loadings of the study. The values of the study's factor loadings were all greater than 0.5 showing a strong convergent validity among the proposed constructs.

\section{Reliability of the Study}

The study's reliability was calculated by using Cronbach's alpha and Composite reliability. The Cronbach alpha coefficients were calculated through SPSS version 24.0 where the loadings ranged from 0.701 to 0.788 which then exceeded the threshold of 0.7. The composite reliability was also calculated using Smart PLS software version 3.0 with values ranging from 0.751 to 0.863 .

\section{Data Collection Techniques}

Marketing managers of the various service companies were contacted through appointments. The idea of conducting the interviews and the distribution of the questionnaires were also discussed. The researchers then adopted "a drop and pick later method" in administering the questionnaires which gave the managers adequate time to complete the questionnaires. The use of follow - up phone calls, texting of messages, sending of emails were all used in facilitating the response rate.

Many of the questionnaires were received through post especially those in Koforidua, Takoradi and Accra where other managers were introduced to the researchers by other marketing managers in the same service companies from the other regions. The completed questionnaires in Kumasi were collected by the researchers while others were made available through branch managers, companies' receptionists and secretaries - where they were all picked at the premises of the companies. The process persisted back and forth from September 2015 to March 2016 until the required sample size of one hundred and sixty-three (163) marketing managers was obtained from the multinational service companies for the study's analysis.

\section{Collected Data from Interviews}

Quantitative survey is usually substantiated with the follow-up interview techniques - a suggestion in the contemporary business literature (Stanko and Bonner, 2013; Siamagka et al., 2015). The authors employed purposive sampling method by selecting marketing managers as respondents who could offer in - depth information in relation to the market orientation activities in the various organisations. Identified managers also referred researchers to their other colleague managers' to assist in the research process as part of the snowballing technique employed in the study. In depth interviews were conducted with eleven marketing managers from their respective firms on appointment basis. The managers were asked to provide information on:

- The type of marketing activities they were applying in the development of their market orientation?

- How were they using the three component: Competitors, customers as well as the interfunctional coordination as part of their market orientation?

- How the named market/marketing orientation influenced the performance of their business?

\section{Data Analysis}

PLS - SEM was employed as the statistical technique in analysing the data. The software used was Smart PLS 3.0. The two-step model of SEM was conducted as suggested by Gerbing and Anderson (1988). The first step was to assess the measurement of the model after which, the hypothesised relationships of the study was assessed in a form of path modeling.

\section{Assessment of Measurement Model}

\section{Reliability}

Reliability is defined as the steadiness and consistency in a study's construct. Reliability of the instrument refers to the extent at which scales generate dependable results when being re-used (Hair et al., 2009). In this study, reliability was assessed using Cronbach alpha and Composite Reliability (CR) as indicated in Table 1, the Cronbach's alpha values ranged from 0.701 to 0.789 which exceeded the recommended threshold opined by Henseler et al. (2009:299). The CR values also ranged from 0.751 to 0.863 as shown in Table 1 .

\section{Validity}

Validity is the extent at which a construct measures what it intends to measure (Hair et al., 1998). In this study, convergent validity and discriminant validity were used to confirm validity. Convergent validity refers to the degree at which a measure of a construct is linked with other measures of the same construct (Babin and Zikmund, 2016: 283). Convergent validity was defined by Ramayah et al. (2011: 419) as the extent at which various items that determine identical variables were in conformity. 
Convergent Validity was assessed through the item factor loadings. Loadings that were less than 0.5 were deleted while those above were used for the study. Table 1 shows all the reflective measurement items with their respective high and significant loadings exceeding the recommended threshold of 0.5 as suggested by Fornell and Larcker (1981; Hair et al., $2010 ; 2009)$. They ranged from 0.526 to 0.983 .

Discriminate validity explains how measurement instrument ought to be discriminated or separated from each construct being studied from other similar constructs (Hair et al., 1998; Babin and Zikmund, 2016: 283). According to Kline (2011), discriminant validity was contrary to convergent validity to the extent that, variables alleged to evaluate different variables illustrate discriminant validity. In the current study, discriminant validity was assessed using the inter - construct correlation matrix by Fornell and Larcker (1981) as well as an average variance extracted values (AVE) exceeding 0.5 .

The study's analysis specified that, the discriminant validity for the variables: Customer orientation, competitor orientation as well as the inter-functional coordination had satisfied Fornell-Lacker criterion where - the square root of the AVE values for each of the individual construct was higher than the cross correlation between that particular construct.

Again, discriminant validity was also assessed using the Average Variance Extracted (AVE) values. According to Fornell and Larcker (1981; Urbach and Ahlemann, 2010; Mayfield and Mayfield, 2012) values of AVE ranging above 0.4 and 0.5 were considered appropriate criteria for exhibiting a discriminant validity. The study's values for AVE values ranged from 0.612 to 0.684 - showing that all the constructs' are satisfactory and hence have good measure of the model as shown in Table 1.

\section{Assessment of Structural Model}

The study's hypotheses were tested and explained below:

In determining the structural model paths coefficients and the statistical consequence or significance of each path; the current study employed Smart PLS 3.0 with bootstrapping as a resampling procedure (300 random samples). Chin (1998) posited that, path coefficients and the $\mathrm{R}^{2}$ are jointly used to evaluate the model while the error estimates and $t$ statistics values were used to check the statistical significance. Values shown in both Figure 2 and Table 3 present the PLS analysis outcome. The statistical significance of the path coefficient permits to identify which of the stated hypotheses supported or rejected the study's propositions. The value for the " $\mathrm{R}^{2}$ " signifies the total of variance described by the independent variables. Chin (1998) also posited that, the lowest t-statistic value of "two" or "2" is usually employed as a yardstick to specify significance of the stated relationships. It is evident from: Figure 2 and Table 3 that, the " $\mathrm{R}^{2}$ " for "Business performance" (BU) was 0.602. It then explains that, the independent variables (Competitor orientation, customer orientation as well as the inter-functional coordination) explained $60.2 \%$ on the dependent variable. The t-statistics depicted significance levels for "Competitor orientation" and "Customer orientation" while "Inter-functional coordination" recorded an insignificant impact on business performance with values such as $0.000,0.020$ as well as 0.147 respectively were obtained as shown in Table 3 .

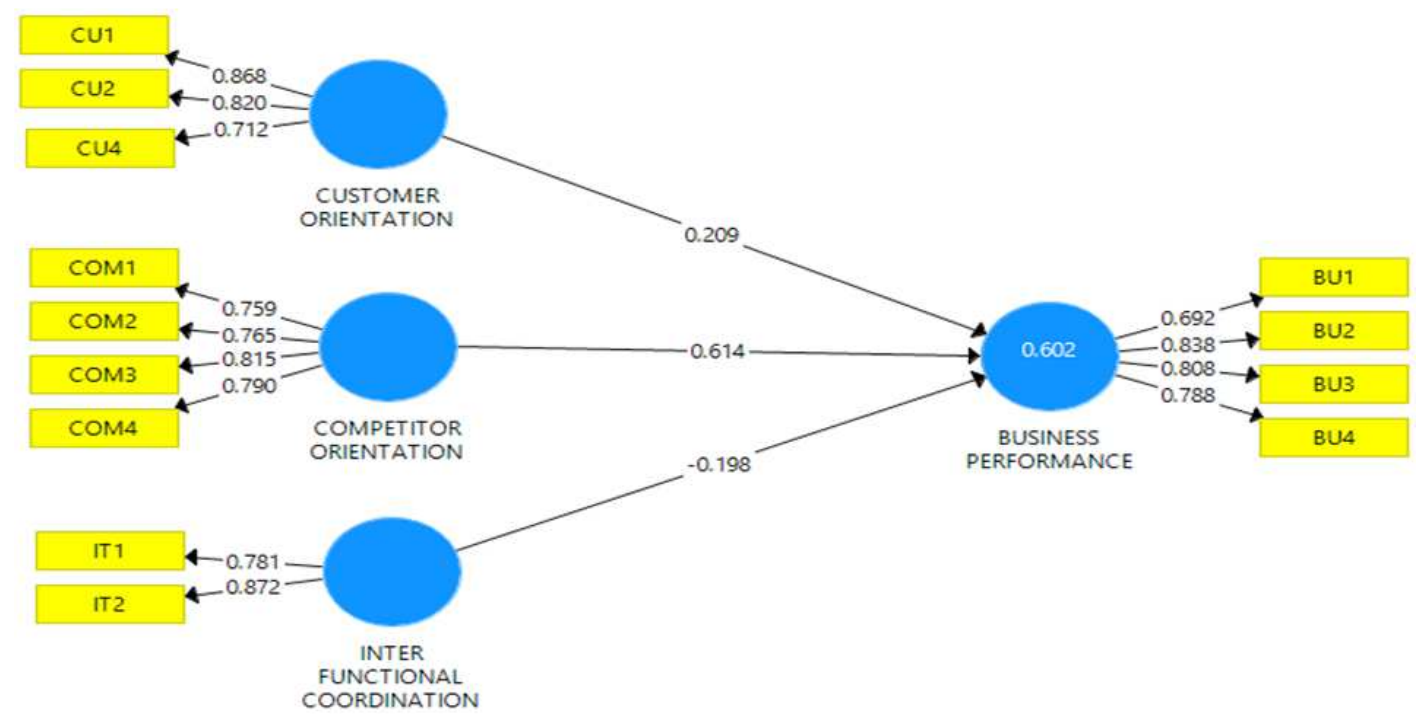

Fig. 2. Structural model results 


\begin{tabular}{|c|c|c|c|c|c|c|}
\hline Research & & R-Squared & Cronbach & Composite & Average & Factor \\
\hline Construct & & Value & Alpha & Reliability & Variance Extracted & Loadings \\
\hline \multirow[t]{3}{*}{$\overline{\mathrm{CU}}$} & CU1 & 0.000 & 0.719 & 0.844 & 0.644 & 0.868 \\
\hline & CU2 & & & & & 0.820 \\
\hline & CU4 & & & & & 0.712 \\
\hline \multirow[t]{2}{*}{ IT } & IT1 & 0.000 & 0.700 & 0.813 & 0.684 & 0.781 \\
\hline & IT2 & & & & & 0.872 \\
\hline \multirow[t]{4}{*}{$\mathrm{COM}$} & COM1 & 0.000 & 0.789 & 0.863 & 0.612 & 0.759 \\
\hline & COM2 & & & & & 0.765 \\
\hline & COM3 & & & & & 0.815 \\
\hline & COM4 & & & & & 0.790 \\
\hline \multirow[t]{4}{*}{$\mathrm{BU}$} & BU1 & 0.587 & 0.788 & 0.863 & 0.614 & 0.692 \\
\hline & BU2 & & & & & 0.838 \\
\hline & BU3 & & & & & 0.808 \\
\hline & BU4 & & & & & 0.788 \\
\hline
\end{tabular}

Table 2. Inter-construct correlation matrix

\begin{tabular}{|c|c|c|c|c|}
\hline Research constructs & $\mathrm{BU}$ & $\mathrm{COM}$ & $\mathrm{CU}$ & IT \\
\hline Business Performance (BU) & 0.782 & & & \\
\hline Competitor orientation (COM) & 0.730 & 0.782 & & \\
\hline Customer orientation (CU) & 0.605 & 0.644 & 0.803 & \\
\hline Inter-functional Coordination (IT) & 0.141 & 0.095 & 0.004 & 0.828 \\
\hline
\end{tabular}

Note: Customer orientation $=\mathrm{CU}$; Competitor orientation $=\mathrm{COM}$; Inter-functional coordination $=$ IT

Table 3. Results of the structural analysis

\begin{tabular}{llllll}
\hline Study's hypothesis & Hypothesis outcome & Path coefficients & T-statistics & P-value & Supported/Rejected \\
\hline CU BU & H1 & 0.209 & 2.348 & 0.013 & Supported \\
COM BU & H2 & 0.614 & 7.177 & 0.000 & Supported \\
IT BU & H3 & -0.198 & 1.452 & 0.147 & Rejected \\
\hline
\end{tabular}

Note: Customer orientation $=\mathrm{CU} ;$ Competitor orientation $=\mathrm{COM}$; Inter-functional coordination $=$ IT while $p<0.05^{* * *}$

The study's Goodness of Fit statistics (GOF) was calculated using a formula by Tenenhaus et al. (2005), where the averages of the Average Variance Extracted (AVE) were first multiplied by the averages of the $\mathrm{R}^{2}$ value, after which the multiplied value was squared to determine the model fit:

$$
\begin{aligned}
& G o F=\sqrt{ } A V E * R^{2} \\
& 0.639 * 0.602 \\
& =\sqrt{ } 0.384678 \\
& =0.6202
\end{aligned}
$$

The calculated global Goodness of Fit (GoF) was 0.604, which exceed the threshold of $\mathrm{GoF}>0.36$ recommended by Wetzels et al. (2009). Thus, the study therefore concluded that, the research model had a superior overall fit.

\section{Findings from the study's interview}

Results from the interview were put into three and they were: Views on marketing or market orientation; how the three components under market oriented activities were applied as well as the influence of marketing activities on business performance.
In the first place, it was observed from the managers that, marketing activities of the companies were purposely controlled by their respective marketing department without involving the views of the other department in their oriented activities. Moreover, the findings on the three component namely - customers, competitors as well as interfunctional coordination were also identified. It became clear that, the focus of the multinational companies was solely on the activities of their competitors - with little attention on customers and inter-functional activities. Managers revealed that, the liberal nature of the Ghana government towards multinationals companies to invest in the country has made it very imperative for managers to monitor their competitors' day in and day out since new companies enter the market at all times. It was observed that, inter-functional coordination among other department on the company's marketing activities was very rare. Finally, managers attested that, their marketing activities had a greater influence on their business performance while limited attention was given to the inter-functional coordination of the companies since every department wanted to be independent in handling their respective activities. 


\section{Findings from Conceptual Model}

The study's Hypothesis (H1) posited a significant positive relationship between "customer orientation" and "Business Performance". The results shown in Fig. 2 and Table 3 supported the hypothesis with a positive and significant relationship of $(0.013)$ with the probability value of (0.209). This result supported the view that, an increased level of customer orientation improves the business performance of multinational companies. Hypothesis 2 (H2) forecasted that, an increased levels of competitor orientation augments the performance of business. The results shown in Fig. 2 and Table 3 again supported the hypothesised relationship with a very strong and significant relationship (0.000) with a probability value of (0.614). The finding therefore provided a support for a significant positive relationship between competitor orientation and business performance in the multinational business activities. Hypothesis 3 (H3) posited a significant positive relationship between inter - functional coordination and business performance. The results in Fig. 2 and Table 3 have showed an insignificant relationship (0.147) with probability value of $(-0.198)$ and therefore rejected the hypothesised relationship.

\section{Discussion of the Study's Findings}

This current study sought to examine the influence of market orientation on business performance among multinational service industries in Ghana. The study relied on the Resource-Based View (RBV) as its theoretical underpinning. Distinctively, the study postulated three hypotheses and in order to test these hypotheses, data were collected from the various marketing managers in Ghana. The empirical results did not support all the postulated research hypotheses in a significant way.

Drawing from the findings of the research, competitor orientation of multinational service activities has a stronger influence on business performance $(0.000)$ more than all the market orientation activities - such as customer orientation as well as the inter functional coordination. Ellis (2006) opined that, a company becomes a competitor oriented once the firm has a reflective insight about the activities of their competitors within the same business environment. This is to say that, multinational service industries in Ghana assess both the strengths and weaknesses of their competitors as observed by Awwad and Agti (2011) as well as Liu et al. (2013) who posited that, such characteristics amount to a strong customer orientation. From the theoretical perspective, it can be concluded that, the inner resources of the multinational service companies also enabled them to have a competitive advantage over their competitors as observed by Barney (2001; Progoulaki and Theotokas, 2010; Merrilees et al., 2011) who revealed that, the resource base of companies are more likely to support them embark on activities in which small organisations will find difficult to embark on. The findings from the interview were also consistent with the results from the survey - where managers attested that, their main focus have always been on their competitors due to the liberalisation policies in attracting multinational industries to Ghana.

Customer orientation on business performance recorded a moderate value of (0.013). According to Aziz and Yassin (2010) and Hillebrand et al. (2011) an astute implementation of customer needs augment the business performance of organizations. The coefficient value of $20 \%$ concentration on customers demonstrated that, multinational service industries were mostly concentrating on market oriented activities at the expense of their customers - who are the life - blood of the companies. According to Kotler and Armstrong (2011:65); Shin (2012) companies that are into customer oriented activities are expected to heighten their market share as well as their effectiveness. The minimal concentration on customers at the expense of competitors is more likely to reduce the profitability levels of the companies.

Findings from inter-functional coordination recorded the least with $(0.147)$ of the total market oriented activities of the multinational service industries in Ghana. According to Awwad and Agti (2011), the interfunctional coordination comprised the idea of integrating all department in the business to develop market information in supporting the entire organisation. The findings of the study have attested that, multinational companies in Ghana were not so much into coordinating the marketing activities among the various department but were solely relying on marketing department in handling activities of the companies' marketing. It was also revealed from the interview with the managers that, marketing department was only responsible for marketing activities without any interference from the other departments. It demonstrated that, the views of the managers who were interviewed were consistent with the results that were obtained from the survey. It also demonstrated that, inter-functional coordination did not have a significant impact on business performance in the multinational companies. Market orientation is solely based on competitor and customer analyses with limited influence of the inter-functional coordinating activities on the performance of business.

\section{Implications of the Study}

The current study makes essential academic and practical contributions to market orientation - business performance literature and practice. To commence with, this study is one of the pioneering studies on market orientation and business performance - which 
measured market orientation from the perspectives of competitors, customers and inter-functional coordination perspective. Many of the studies on market orientation and business performance are measured as a uni-dimensional. The idea of separating the concept brought new insight to the fact that, companies were solely relying on their competitors and customers at the expense of integrating activities of marketing together - something previous researchers have made in the academic literature. Moreover, the use of marketing managers' views on market orientation makes it more viable in understanding market oriented activities of the companies other than the general managers' view as observed in many of the studies in the extant literature. In addition, excessive concentration on competitors by the multinational companies other than the taste and preferences of the customers ought to be assessed by the marketing managers as part of their long term plans to remain in Africa. Attention is expected to be given to the different customers from different cultural background - since Africa and many of the developing countries are espoused to their cultural heritage in terms of receptive advertising, promotion, personal selling and other marketing activities that are geared towards the customers. Finally, the finding of the current study is expected to add to the academic literature on the need to measure market orientation as a multidimensional construct. It is also expected to improve the service multinational sectors in Africa. The MNC marketing managers are expected to be aware of the trend in their marketing pattern - thereby making provisions in handling unforeseen situations which could affect the companies. According to Mokhtar et al. (2014) many organizations obliges their administration to pay attention and identify customer needs towards the improvement of their companies' market position.

\section{Contribution of the Study}

The study's contribution is in three phase: First and foremost, the findings from the empirical study advance the market orientation literature by pointing out that, the association between customer orientation, competitor orientation as well as the inter - functional orientation on business performance have diverse view than previously assumed in the extant literature-especially in the developing countries. In addition, the results also fill the void on the scant literature of multinational companies' activities in Africa as well as the use of marketing managers' views to effectively evaluate market oriented activities of companies.

\section{Acknowledgment}

This is part of an exertion to advance academic knowledge in both marketing and management literature-especially on multinational companies and marketing managers as drivers of market oriented activities in organisations. Part of the funds came from the Post Graduate Merit Award scholarship from the University of the Witwatersrand in South Africa. Data relating to the study were sourced from different marketing managers in Ghana. Preceding works in the study's area are acknowledged as well as the anonymous reviewers of this manuscript.

\section{Author's Contributions}

Martin Owusu Ansah: Designed the study, wrote the preliminary outline, conducted the interviews, took part in the data collection process with the help of contracted research assistants, structured the literature review, analysed the collected data and reviewed the original draft.

Richard Chinomona: Reviewed the original draft from the introduction to conclusion and made significant comments towards the completion of the study. Both authors gave consent to the final submitted manuscript.

\section{Ethics}

This study presents original findings, which make contribution to multinational studies and on marketing manager's activities in both marketing and management literature. The contents are the viewpoint of the authors and not necessarily the journal publishers. The research has not been published elsewhere or is it being considered for publication in any other journal.

\section{References}

Agrawal, D.K., 2012. Demand chain management: factors enhancing market responsiveness capabilities. J. Market. Channels, 19: 101-119.

Ansah, O.M., 2016. The influence of culture, market environment and e-marketing adoption on business performance of multinational companies in Ghana: Marketing managers' perspective. PhD Thesis, University of the Witwatersrand, South Africa.

Attia, S.T.M., 2013. Market orientation in an emerging economy-Egypt. J. Strategic Market., 21: 277-291. DOI: 10.1080/0965254X.2013.768690

Awwad, M.S. and D.A.M. Agti, 2011. The impact of internal marketing on commercial banks' market orientation. Int. J. Bank Market., 29: 308-332. DOI: $10.1108 / 02652321111145943$

Aziz, N.A. and N.M. Yasin, 2010. How will market orientation and external environmnet influence the performance among SMEs in the agri-food sector in Malaysia? Int. Bus. Res., 3: 154-154.

DOI: $10.5539 /$ ibr.v3n3p154 
Babin, B. and W. Zikmund, 2016. Exploring Marketing Research. 11th Edn., Cengage Learning, ISBN-10: 1305831241, pp: 656.

Bahman, H. and G. Mehdi, 2011. The impact of market orientation and organizational culture on the performance: Case study of SMEs. J. Contemporary Manage.

Baker, W. and J. Sinkula, 2009. The complementary effects of market orientation and entrepreneurial orientation on profitability in small businesses. J. Small Bus. Manage., 47: 443-464. DOI: 10.1111/j.1540-627X.2009. 00278.x

Barney, J.B., 2001. Is the resource-based "view" a useful perspective for strategic management research? Acad. Manage. Rev., 26: 41-56.

Buckley, P. and M. Casson, 2009. The internalisation theory of the multinational enterprise: A review of the progress of a research agenda after 30 years. J. Int. Bus. Stud., 40: 1563-1580. DOI: 10.1057/jibs.2009.49

Cano, C.R., F.A. Carrillat and F. Jaramillo, 2004. A metaanalysis of the relationship between market orientation and business performance: Evidence from five continents. Int. J. Res. Market., 21: 179-200.

Capon, N., J.U. Farley and S. Hoenig, 1990. Determinants of financial performance: A metaanalysis. Manage. Sci., 36: 1143-1159.

DOI: $10.1287 / \mathrm{mnsc} .36 .10 .1143$

Chin, W.W., 1998. Issues and opinion on structural equation modelling. MIS Q., 22: 7-16.

Chin, W.W., 2010. How to Write up and Report PLS Analyses. In: Handbook of Partial Least Squares, Esposito, V.V., W.W. Chin, J. Henseler and H. Wang (Eds.), Springer, pp: 655-690.

Comu, S., H.I. Unsal and J.E. Taylor, 2011. Dual impact of cultural and linguistic diversity on project network performance. J. Manage. Eng.., 27: 179-187. DOI: 10.1061/(ASCE)ME.1943-5479.0000052

Dubihlela, J., 2013. Determinants of market orientation adoption among Small and Medium Enterprises (SMES) in South Africa. Mediterranean J. Soc. Sci., 4: 55. DOI: 10.5901/mjss. 2013.v4n6p55

Dwairi, M., S. Bhuian and A. Jurkus, 2007. Revisiting the pioneering market orientation model in an emerging economy. Eur. J. Market., 41: 713-721. DOI: $10.1108 / 03090560710752357$

Edigheji, O.E., 2010. Constructing a democratic developmental State in South Africa: Potentials and Challenges. Human Science Research Council Press, Cape Town.

Ellis, P.D., 2006. Market orientation and performance: A meta-analysis and cross-national comparisons. J. Manage. Stud., 43: 1089-1107.

DOI: $10.1111 / \mathrm{j} .1467-6486.2006 .00630 . x$
Fornell, C. and D.F. Larcker, 1981. Evaluating structural equation models with unobservable variables and measurement error. J. Market. Res., 18: 39-50. DOI: $10.2307 / 3151312$

Fraj-Andrés, E., E. Martinez-Salinas and J. Matute-Vallejo, 2009. A multidimensional approach to the influence of environmental marketing and orientation on the firm's organizational performance. J. Bus. Eth., 88: 263-286. DOI: 10.1007/s10551-008-9962-2

Gerbing, D.W. and J.C. Anderson, 1988. An updated paradigm for scale development incorporating unidimensionality and its assessment. J. Market. Res., 25: 186-192. DOI: 10.2307/3172650

Ghouri, A.M., N.U.R. Khan, M.A. Malik and A. Razzaq, 2011. Marketing practices and their effects on firm's performance: Findings from small and medium sized catering and restaurants in Karachi. Int. J. Bus. Manage., 6: 251-259. DOI: $10.5539 / \mathrm{ijbm} . v 6 \mathrm{n} 5 \mathrm{p} 251$

Hair, J.F., R.E. Anderson, R.L. Tatham and W. Black, 1998. Multivariate Data Analysis. 1st Edn., Prentice Hall, Upper Saddle River.

Hair, J.F., R.P. Bush and D.J. Ortinau, 2009. Marketing Research: In a Digital Information Environment. 4th Edn., McGraw-Hill Higher Education, Cape Town, ISBN-10: 0071101071, pp: 690.

Hair, J.F., W.C. Black, B.J. Babin and R.E. Anderson, 2010. Multivariate Data Analysis. 7th Edn, PrenticeHall, Upper Saddle River.

Hajipour, B., M. Bagheri and M. Ghanavati, 2010. The impact of socio-cultural innovation and brand management on financial performance and brand performance of the companies listed in Tehran stock exchange. Res. J. Int. Stud., 15: 55-68.

Henseler, J., C.M. Ringle and R.R. Sinkovics, 2009. The use of partial least squares path modeling in international marketing. Adv. Int. Market., 20: 277-320.

DOI: $10.1108 / \mathrm{S} 1474-7979(2009) 0000020014$

Herhausen, D., 2016. Unfolding the ambidextrous effects of proactive and responsive market orientation. J. Bus. Res., 69: 2585-2593.

DOI: 10.1016/j.jbusres.2015.10.139

Hillebrand, B., R.G. Kemp and E.J. Nijssen, 2011. Customer orientation and future market focus in NSD. J. Service Manage., 22: 67-84. DOI: $10.1108 / 09564231111106929$

Hortinha, P., C. Lages and L.F. Lages, 2011. The tradeoff between customer and technology orientations: Impact on innovation capabilities and export performance. J. Int. Market., 19: 36-58.

DOI: $10.1509 /$ jimk.19.3.36

Hult, G. and M. Tomas, 2011. Market-focused sustainability: Market orientation plus? J. Acad. Market. Sci., 39: 1-6. DOI: 10.1007/s11747-010-0223-4 
Kline, R.B., 2011. Principles and Practice of Structural Equation Modeling. 3rd Edn., Guildford Press, New York, ISBN-10: 1606238760, pp: 427.

Kohli, A.K. and B.J. Jaworski, 1996. Market orientation: Review, refinement and roadmap. J. MarketFocused Manage., 1: 119-135. DOI: $10.1007 / \mathrm{BF} 00128686$

Kotler, P. and G. Armstrong, 2011. Principles of Marketing. 14th Edn., Prentice-Hall, Boston.

Kotler, P., 1994. Marketing Management. 8th Edn., Prentice-Hall, Inc., Englewood Cliffs, N.J.

Kotler, P., 2010. Marketing management. Prentice Hall of Idia Private Limited, New Delhi.

Kumar, R. R., Subramanian, R. and K. Strandholm, 2011. Market orientation and performance: Does organizational strategy matter? J. Applied Bus. Res., 18: 37-49. DOI: 10.19030/jabr. v18i1.2099

Kumar, V., E. Jones, R. Venkatesan and R.P. Leone, 2011. Is market orientation a source of sustainable competitive advantage or simply the cost of competing? J. Market., 75: 16-30. DOI: $10.1509 / j m k g .75 .1 .16$

Kurt, M., G. Sonja and B. Sonja, 2006. The value-brand trust-brand loyalty chain: An analysis of some moderating variables. J. Innovative Market., 2: 76-88.

Lado, N. and A. Maydeu-Olivares, 2001. Exploring the link between market orientation and innovation in the European and US insurance markets. Int. Market. Rev., 18: 130-145.

DOI: $10.1108 / 02651330110389972$

Lai, C.S., D.C. Pai, C.F. Yang and H.J. Lin, 2009. The effects of market orientation on relationship learning and relationship performance in industrial marketing: The dyadic perspectives. Indust. Market. Manage., 38: 166-172.

DOI: $10.1016 /$ j.indmarman.2008.12.004

Lee, D.D. and R. Madhavan, 2010. Divestiture and firm performance: A meta-analysis. J. Manage., 36: 1345-1371. DOI: 10.1177/0149206309360931

Liu, H., W. Ke, K.K. Wei and Z. Hua, 2013. Effects of supply chain integration and market orientation on firm performance: Evidence from China, Int. J. Operat. Product. Manage., 33: 322-346. DOI: $10.1108 / 01443571311300809$

Mahmoud, M.A., A. Kastner and J. Yeboah, 2010. Antecedents, environmental moderators and consequences of market orientation: A study of pharmaceutical firms in Ghana. J. Med. Market., 10: 231-244. DOI: 10.1057/jmm.2010.12

Mashahadia, F., N.H. Ahmadb and O. Mohamad, 2016. Market orientation and innovation ambidexterity: A synthesized model for internationally Operated Herbal-based Small and Medium Enterprises (HbSMEs). Proc. Econom. Finance, 37: 145-151. DOI: $10.1016 / \mathrm{S} 2212-5671(16) 30105-8$
Mayfield, J. and M. Mayfield, 2012. The relationship between leader motivating language and selfefficacy: A partial least squares model analysis. J. Bus. Commun., 49: 357-376.

McCarthy, E.J. and W.D. Jr. Perreault, 1993. Basic Marketing. 11th Edn., Richard D. Irwin, Inc., Homewood, Ill.

Merchant, K.A., W.A. Van der Stede, T.W. Lin and Z. Yu, 2011. Performance measurement and incentive compensation: An empirical analysis and comparison of Chinese and Western firms' practices. Eur. Account. Rev., 20: 639-667. DOI: $10.1080 / 09638180.2011 .593293$

Merrilees, B., S. Rundle-Thiele and A. Lye, 2011. Marketing capabilities: Antecedents and implications for B2B SME performance. Indust. Market. Manage., 40: 368-375.

DOI: 10.1016/j.indmarman.2010.08.005

Mokhtar, S.S.M., R.Z. Yusoff and A. Ahmad, 2014. Key elements of market orientation on Malaysian SMEs performance. Int. J. Bus. Society, 15: 49-64.

Morgan, N.A., D.W. Vorhies and C.H. Mason, 2009. Market orientation, marketing capabilities and firm performance. Strategic Manage. J., 30: 909-920. DOI: $10.1002 / \mathrm{smj} .764$

Murphy, W.H. and N. Li, 2012. A multi-nation study of sales manager effectiveness with global implications. Indust. Market. Manage., 41: 1152-1163. DOI: 10.1016/j.indmarman.2012.06.012

Murray, J.Y., G.Y. Gao and M. Kotabe, 2011. Market orientation and performance of export ventures: The process through marketing capabilities and competitive advantages. J. Acad. Market. Sci., 39: 252-269.

Narver, J.C. and S.F. Slater, 1990. The effect of a market orientation on business profitability. J. Market., 54: 20-35. DOI: $10.2307 / 1251757$

Neely, A., 2002. Business performance measurement: Theory and practice. Cambridge University Press.

Ngo, L.V. and A. O'Cass, 2012. Performance implications of market orientation, marketing resources and marketing capabilities. J. Market. Manage., 28: 173-187.

DOI: $10.1080 / 0267257 X .2011 .621443$

OECD, 2008. Organisation for Economic Co-operation and Development. Factbook 2008. OECD Publishing.

O'Sullivan, D. and P. Butler, 2009. Market orientation and enterprise policy. Eur. J. Market., 43: 1349-1364. DOI: 10.1108/03090560910989920

Olavarrieta, S. and R. Friedmann, 2008. Market orientation, knowledge-related resources and firm performance. J. Bus. Res., 61: 623-630. DOI: $10.1016 /$ j.jbusres.2007.06.037 
Özturan, P., A. Özsomer and R Pieters, 2014. The role of market orientation in advertising spending during economic collapse: The case of turkey in 2001. J. Market. Res., 51: 139-152.

DOI: $10.1509 /$ jmr.11.0528

Progoulaki, M. and L. Theotokas, 2010. Human resource management and competitive advantage: An application of resource-based view in the shipping industry. Marine Policy, 34: 575-582. DOI: 10.1016/j.marpol.2009.11.004

Puck, J.F., A.T. Mohr and D. Rygl, 2008. An empirical analysis of managers' adjustment to working in multi-national project teams in the pipeline and plant construction sector. Int. J. Human Resource Manage., 19; 12: 2252-2267.

DOI: $10.1080 / 09585190802479488$

Racela, O.C., C. Chaikittisilpa and A. Thoumrungroje, 2007. Market orientation, international business relationships and perceived export performance. Int. Market. Rev., 24: 144-163. DOI: $10.1108 / 02651330710741794$

Ramayah, T., J.W.C. Lee and J.B.C. In, 2011. Network collaboration and performance in the tourism sector. Service Bus., 5: 411-28. DOI: $10.1007 / \mathrm{s} 11628-011-0120-\mathrm{z}$

Ruekert, R. W., O. C. Walker Jr. and K. J. Roering, 1985. The organization of marketing activities: A contingency theory of structure and performance. J. Market.

Salminen, M., 2006. Innovaatioyrittäjä jää laakereille lepäämään. Kauppalehti, 12: 18-19.

Šályová, S., J. Táborecká-Petrovičováa, G. Nedelováa and J. Dasoa, 2016. Effect of marketing orientation on business performance: A study from Slovak foodstuff industry. Proc. Econom. Finance, 34: 622-629. DOI: 10.1016/S2212-5671(15)01677-9

Shah, F.A., R.M. Yusaff, A. Hussain and J. Hussain, 2012. A Critical review of multinational companies, their structures and strategies and their link with international human resource management. J. Bus. Manage., 3: 28-37.

Shin, S., 2012. Decomposed approach of market orientation and marketing mix capability: Research on their relationships with firm performance in the Korean context. Int. Bus. Res., 5: 22-33. DOI: $10.5539 /$ ibr. v5n1p22

Siamagka, N., G. Christodoulides, N. Michaelidou and A. Valvi, 2015. Determinants of social media adoption by B2B organizations. Indust. Market. Manage., 51: 89-99.

DOI: $10.1016 /$ j.indmarman.2015.05.005

Slater, S. and J. Narver, 1994. Does competitive environment moderate the market orientationperformance relationship. J. Market., 58: 46-55. DOI: $10.2307 / 1252250$
Smirnova, M., P. Naudé, S.C. Henneberg, S. Mouzas and S.P. Kouchtch, 2011. The impact of market orientation on the development of relational capabilities and performance outcomes: The case of Russian industrial firms. Indust. Market. Manage., 40: 44-53. DOI: 10.1016/j.indmarman.2010.09.009

Spero, J.E. and J.A. Hart, 2010. The Politics of International Economic Relations. 7th Edn., Wadsworth Cengage Learning, Boston, ISBN-10: 0495797391, pp: 504.

Spillan, J.E., K. Ali, O.K. Domfeh and J.M. McGinnis, 2013. Market orientation and firm performance: An empirical analysis of Ghanaian microenterprises. J. Global Market., 26: 258-272.

DOI: $10.1080 / 08911762.2013 .825040$

Stanko, M.A. and J.M. Bonner, 2013. Projective customer competence: Projecting future customer needs that drive innovation performance. Indust. Market. Manage., 42: 1255-1265.

DOI: $10.1016 /$ j.indmarman.2013.05.016

Suliyanto, S. and R. Rahab, 2012. The role of market orientation and learning orientation in improving innovativeness and performance of small and medium enterprises. Asian Soc. Sci., 8: 134-145. DOI: $10.5539 /$ ass. v8n1p134

Tenenhaus, M., V.E. Vinzi, Y.M. Chatelin and C. Lauro, 2005. PLS path modeling. Comput. Stat. Data Anal., 48: 159-205. DOI: 10.1016/j.csda.2004.03.005

Theodosiou, M., J. Kehagias and E. Katsikea, 2012. Strategic orientations, marketing capabilities and firm performance: An empirical investigation in the context of frontline managers in service organizations. Indust. Market. Manage., 41: 1058-1070.

DOI: 10.1016/j.indmarman.2012.01.001

UNCTAD, 2009. Economic Development in Africa Report 2009: Strengthening Regional Economic Integration for Africa's Development. United Nations Conference on Trade and Development (UNCTAD). Geneva, Switzerland.

Urbach, N. and F. Ahlemann, 2010. Structural equation modeling in information systems research using partial least squares. J. Inform. Technol. Theory Applic., 11: 5-39.

Van Raaij, E.M. and J.W. Stoelhorst, 2008. The implementation of a market orientation: A review and integration of the contributions to date. Eur. J. Market., 42: 1265-1293. DOI: 10.1108/03090560810903673

Verbekea, A., L. Kanob and W. Yuanc, 2016. Inside the regional multinationals: A new value chain perspective on subsidiary capabilities. Int. Bus. Rev., 25: 785-793.

DOI: 10.1016/j.ibusrev.2016.01.019 
Vieira, V.A., 2010. Antecedents and consequences of market orientation: A Brazilian meta-analysis and an international mega-analysis. Brazil. Admin. Rev., 7: 40-58.

Wernerfelt, B., 1984. A resource-based view of the firm. Strategic Manage. J., 5: 171-180.

DOI: $10.1002 / \mathrm{smj} .4250050207$

Wetzels, M., G. Odekerken-Schröder and C. Van Oppen, 2009. Using PLS path modeling for assessing hierarchical construct models: Guidelines and empirical illustration. Manage. Inform. Syst. Q., 33: 177-195.
Yoon, S.J. and S.H. Lee, 2005. Market-oriented culture and strategy: Are they synergistic? Market. Bull., 16: $1-20$.

Zebal, M.A. and D.R. Goodwin, 2012. Market orientation and performance in private universities. Market. Intell. Plann., 30: 339-357.

DOI: $10.1108 / 02634501211226302$ 